удк 330.34 .1

\title{
ОСОБЛИВОСТІ ТА ПРОБЛЕМИ ВПРОВАДЖЕННЯ ІНДУСТРІї 4.0 В УКРАЇНІ
}

\section{FEATURES AND PROBLEMS OF INDUSTRY 4.0 IMPLEMENTATION IN UKRAINE}

\author{
Джафрарова Ельвіра Самідівна \\ студентка, \\ Київський національний торговельно-економічний університет \\ ORCID: https://orcid.org/0000-0003-0910-7560 \\ Карпенко Марина Олександрівна \\ кандидат економічних наук, \\ Київський національний торговельно-економічний університет \\ ORCID: https://orcid.org/0000-0003-4393-7429
}

Dzhafarova Elvira, Karpenko Marina

Kyiv National University of Trade and Economics

\begin{abstract}
Стаття присвячена актуальним питанням особливостей впровадження індустрії 4.0 в Україні. Світове визнання переваг концепції «Індустрія 4.0» робить необхідним здійснення аналізу досвіду впровадження технологій «Індустрії 4.0» у діяльність вітчизняних підприємств, а також визначення можливостей переходу національної економіки до «нндустрії 4.0». У статті визначено особливості та проблемні аспекти впровадження та розвитку стратегії «Індустрія 4.0» в Україні. Проаналізовано можливості, завдяки яким технології «Індустрії 4.0» можуть бути впроваджені на підприємствах Україні. Визначено лідерів серед інноваційних компаній України. Охарактеризовано впровадження та розвиток «Індустрії 4.0» в Україні в різних сорерах діяльності, зокрема, в енергетиці, рітейлі, АПК, фрінансах, будівництві, фрармацевтиці, транспорті і логістиці, машинобудуванні та досліджено ймовірні наслідки розвитку «Індустрії 4.0» в Україні.
\end{abstract}

Ключові слова: стратегія, Індустрія 4.0, інновації, промислова революція, цифровізація, проекти, автоматизоване виробництво.

Статья посвящена актуальным вопросам особенностей внедрения индустрии 4.0 в Украине. Мировое признание преимуществ концепции «Индустрия 4.0» делает целесообразным осуществление анализа опыта внедрения технологий «Индустрии 4.0» в деятельности отечественных предприятий, а также определение возможностей перехода национальной экономики к «Индустрии 4.0». В статье определены особенности и проблемные аспекты внедрения и развития стратегии «Индустрия 4.0» в Украине. Проанализированы возможности, благодаря которым технологии «Индустрии 4.0» могут быть внедрены на предприятиях Украины. Определены лидеры среди инновационных компаний Украины. Охарактеризовано внедрение и развитие «Индустрии 4.0» в Украине в различных сорерах деятельности,

Ключевые слова: стратегия, Индустрия 4.0, инновации, промышленная революция, цифровизация, проекты, автоматизированное производство.

Every year, digital transformation occupies an increasingly important place in our lives. In 2021, the issue of digitalization of the economy is quite acute among the key priorities of the country's strategic and economic development. Digitalization penetrates almost all areas of industry and services, makes irreversible changes in the management of companies, improving their financial and economic activities and making them more flexible and competitive in the market. It is the use of powerful software, hardware and digital tools that forms the company's competitive advantages in the market. Digitalization opens up many new opportunities for organizations to further develop effectively and is an effective mechanism for implementing positive changes in companies. Therefore, the processes of digitalization are quite relevant and require more thorough research in modern conditions. In the process of writing the article, the following scientific methods were used: methods of analysis and synthesis, method of generalization of research results, etc.methods of the theory of knowledge, which helped to consider and characterize the essence, significance and features of the digital transformation process in Ukrainian enterprises. The article is devoted to topical issues of the implementation of «Industry 4.0» in Ukraine. The global recognition of the advantages of the 
«Industry 4.0» concept makes it necessary to analyze the experience of implementing «Industry 4.0» technologies in the activities of domestic enterprises, as well as determine the possibilities of transition of the national economy to «Industry 4.0». The article defines the features and problematic aspects of implementing and developing the «Industry 4.0» strategy in Ukraine. The article analyzes the opportunities that allow «Industry 4.0» technologies to be implemented at Ukrainian enterprises. Leaders among innovative companies in Ukraine have been identified. The article describes the introduction and development of «Industry 4.0» in Ukraine in various fields of activity, in particular, in the energy, retail, agro-industrial complex, finance, construction, pharmaceuticals, transport and logistics, mechanical engineering, and examines the likely consequences of the development of «Industry 4.0» in Ukraine.

Keywords: strategy, Industry 4.0, innovation, industrial revolution, digitalization, projects, automated production.

Постановка проблеми. За останні десятиліття істотно почали змінюватися підходи до ведення господарської діяльності. Це обумовлено швидким поширенням передових досягнень четвертої промислової революції на основі інформаційної складової [1]. Розвиток інтернету, інтернету речей (IoT), інфрормаційно-комунікаційних технологій (5G), стійких каналів зв'язку, хмарних технологій, використання штучного інтелекту на основі великих не структурованих масивів даних (Big Data) i цифрових платформ забезпечило появу відкритих інформаційних систем і глобальних промислових мереж, що виходять за межі окремого підприємства і взаємодіючих між собою. Такі системи і мережі надають перетворюючий вплив на всі сектори сучасної економіки і бізнесу і переводять промислову автоматизацію на новий четвертий рівень індустріалізації.

Четверта промислова революція перестала бути просто концепцією, стандарти «Індустрії 4.0» вже активно впроваджуються, зокрема на підприємствах в Європі, тоді як відставання України збільшується. Невирішеним залишається питання широкого впровадження принципів «Індустрії 4.0» на підприємствах України та цифровізація промисловості загалом.

Таким чином, проблематика полягає в наступному: в першу чергу, недостатньо вивчений досвід країни по впровадженню і реалізації промислової політики і цифрової трансорормації, також проблемою $€$ повільне впровадження цифрровізації промисловості порівняно $з$ іншими країнами.

Аналіз останніх досліджень і публікацій. Серед вітчизняних науковців, які досліджують проблеми розвитку Індустрії 4.0 та цифрової економіки, слід виокремити таких: О. Амоша [2, с. 58] - розглядає вплив і перспективи впровадження Індустрії 4.0 для промисловості; І. Булєєв [3, с. 116-132] - обґрунтовує парадигму активізації інвестиційної діяльності підприємств в умовах системної кризи і падаючих ринків, метою якої є розвинена про- мисловість 3 Індустрією 4.0; В. Вишневський, О. Вієцька, О. Гаркушенко, С. Князєв, О. Лях, В. Чекіна, Д. Череватський [4, с. 192] - досліджують перспективи, напрями і механізми смарт-промисловості та цифрової економіки. Зарубіжні дослідники, такі як Е. Бріньолфсон та Е. Макафрі [5, с. 384], стверджують, що сучасні технології скоро залишать людей без робочих місць; С. Грінгард [6, с. 73] доводить, що майбутнє саме за технікою, підключеною до мережі, та описує, як зміниться світ, у якому всі матеріальні предмети зможуть обмінюватися інорормацією; П. Плеханов [7, с. 273-275] здійснює спробу оцінки значущості революційних нововведень для економіки та розгляду їх як ознаки четвертої промислової революції; Д. Ріфкін [8, с. 291] вважає, що на зміну традиційним централізованим моделям бізнесу в найближчі півстоліття мають прийти нові структури, а саме спадщина першої та другої промислових революцій - ієрархічна організація економічної та політичної влади неминуче поступиться місцем горизонтальній взаємодії; Д. Роджерс [9, с. 296] надає практичні інструменти, які допоможуть компаніям і бізнес-лідерам будь-якого масштабу адаптувати й упроваджувати інновації, перемагати в конкурентній боротьбі; у книзі А. Росса [10, с. 286] йдеться про індустрії, які стануть головними драйверами економічних і соціальних змін в найближчі 20 років; Ч. Хенді [11, с. 445] дає відповіді на питання про вплив на життя прийдешніх невідворотних змін, як до них підготуватися; К. Шваб [12, с. 208] розкриває особливості й головні тренди четвертої промислової революції, фрормує комплексне уявлення про те, як технології змінюють наше життя і життя майбутніх поколінь; Я. Сміт, С. Крейцер, К. Меллер, М. Карлберг [13, с. 1-94] розглядають економічну та соціальну політику держав у сорері «Індустрії 4.0» та ін.

Виділення невирішених раніше частин загальної проблеми. У світі відбувається масштабна цифровізація всіх галузей економіки та базових сорер життя, збільшення інвестицій у розвиток інфрраструктури, інно- 
вації та сучасні технології. Адже цифрові технології знижують бар'єри для виходу на нові ринки, дозволяють автоматизувати величезний обсяг механічної роботи, модернізувати обладнання, оптимізувати процеси управління. Важливий аспект: завдяки впровадженню цифрової економіки малий і середній бізнес стає глобальним, українські компанії мають можливість інтегруватися в міжнародні мережі $з$ доданою вартістю.

Незважаючи на велику кількість публікацій щодо стану та перспектив впровадження «Індустрії 4.0» в Україні, на нашу думку недостатньо висвітленими залишаються питання особливостей впровадження та розвитку технологій «Індустрії 4.0» в енергетиці, рітейлі, АПК, фрінансах, будівництві, фрармацевтиці, транспорті та логістиці, машинобудуванні.

Формулювання цілей статті (постановка завдання). Метою даної статті $€$ обґрунтування основних теоретичних підходів, особливостей та проблем щодо впровадження і фрормування напрямів розвитку «Індустрії 4.0» в Україні.

Виклад основного матеріалу дослідження. «Індустрія 4.0»- перехід на повністю автоматизоване цисррове виробництво, кероване інтелектуальними системами в реальному часі в постійній взаємодії із зовнішнім середовищем, що виходить за межі одиничного підприємства, 3 перспективою об'єднання в глобальну промислову мережу речей і послуг [14].

В Україні технології «нндустрії 4.0» поступово проникають у різні сектори економіки, проте із значно меншими масштабами, ніж це відбувається в інших високорозвинених країнах. Аналіз співвідношення експорту та імпорту IT-продукції показує, що для країн-лідерів за експортом-імпортом інфрормаційно-комунікаційних технологій є суттєвий рівень кореляції між експортом та імпортом, і Україна також відповідає загальносвітовому тренду [15].

Українські компанії, прагнучи підвищити есрективність власної діяльності та наблизитися до міжнародних стандартів, впроваджують інноваційні рішення, «розумні» пристрої, які автоматизують окремі процеси для оптимізації виробництва.

У таблиці 1 представлено лідерів серед інноваційних компаній України станом на 2020 рік, які розробили новий або поліпшили існуючий продукт, технологію або послугу, та які використовують інновації в управлінні бізнес-процесами (у виробництві, логістиці, управлінні, фрінансах і продажах).
В Україні присутні не лише підприємства, які використовують досягнення «Індустрії 4.0» у власній діяльності, а й компанії, що займаються розробкою та виробництвом програмного забезпечення, пристроїв та елементів, що притаманні «ндустрії 4.0», на замовлення українських та іноземних компаній.

Протягом останніх років спостерігається тенденція підвищення рівня доступу аграрних компаній до передових технологій. Так, у своїй діяльності невеликі фрермерські господарства активно застосовують квадрокоптери, роботизовані процеси, різні сенсори та датчики, хоча раніше такі технології мали можливість використовувати лише великі агрохолдинги.

Досягнення «Індустрії 4.0» активно впроваджує у свою діяльність один із найбільших агрохолдингів України «Укрлендфрармінг». Компанія володіє власною телеметричною системою «Свій-Чужий», яка передбачає збір даних з усіх одиниць техніки за допомогою GPS-трекерів, про переміщення, швидкість, використання палива, показники навантаження на двигун. Дана система не лише забезпечує облік врожаю, а й запобігає виникненню крадіжок та порушенню правил роботи на полях [17].

Крім застосування українськими аграрними підприємствами у своїй діяльності зарубіжних інноваційних розробок, українські компанії та науковці активно здійснюють проектування та реалізацію перспективних рішень для аграрного сектору на основі елементів «Індустрії $4.0 »$ (таблиця 2).

Технології вітчизняних розробників викликають зацікавленість як у вітчизняних, так і в іноземних партнерів, оскільки вони не лише дозволяють знизити собівартість, ефрективно використовувати ресурси, покращити врожайність, автоматизувати та контролювати виробничі процеси в компаній, а й мають нижчу ціну, ніж світові аналоги.

Інноваційні технології та розробки також втілюються на українських підприємствах, які займаються відновлювальною енергетикою. Компанії «Вінд Пауер» та «Еко-Оптіма», що фрункціонують в цій сорері, увійшли до рейтингу найбільш інноваційних компаній України [18].

«Індустрія 4.0» та її основні характеристики поступово проникають у діяльність українських машинобудівних підприємств. Виробники все більше практикують використання «розумних» пристроїв, автоматизацію окремих процесів та інші технології «Індустрії 4.0» [19].

Таким чином, впровадження та використання досягнень «Індустрії 4.0» вітчизняними компаніями здійснюється повільно в порів- 
Таблиця 1

Рейтинг лідерів інноваційних компаній України по галузі за 2020 рік

\begin{tabular}{|c|c|c|}
\hline Назва компанії & Галузь & Суть інновації \\
\hline Метінвест & Промисловість & $\begin{array}{l}\text { На ММК імені Ілліча модернізували листопрокатний стан } \\
\text { «1700» }\end{array}$ \\
\hline ДТЕК Нафртогаз & $\begin{array}{l}\text { Енергетика } \\
\text { і нафттогаз }\end{array}$ & $\begin{array}{l}\text { «ДТЕК Нафтогаз» реалізує проект створення цифрового } \\
\text { родовища для підвищення ефективності видобутку } \\
\text { газу на великих глибинах, а також для розробки } \\
\text { важкодобувних запасів газу. }\end{array}$ \\
\hline Сільпо & Рітейл & $\begin{array}{l}\text { Свої дизайнерські магазини компанія оформляє в } \\
\text { оригінальному концепті, поєднуючи традиційний рітейл } 3 \\
\text { фруд-кортом }\end{array}$ \\
\hline $\mathrm{ABK}$ & FMCG & $\begin{array}{l}\text { У компанії змінили ринки збуту і асортимент. За чотири } \\
\text { роки вийшли на ринки } 60 \text { країн. Піонер у виготовленні } \\
\text { снеків екструзійним способом. }\end{array}$ \\
\hline МХП & АПК & $\begin{array}{l}\text { Компанія реалізувала наймасштабніший інноваційний } \\
\text { проект - біогазовий напрямок бізнесу, сировиною для } \\
\text { якого став курячий послід }\end{array}$ \\
\hline $\begin{array}{l}\text { Альфра-Банк } \\
\text { Україна }\end{array}$ & Фінанси & $\begin{array}{l}\text { Альфра-Банк у партнерстві з платформою відкритих } \\
\text { iнновацій RE: ACTOR запустив технологічну онлайн- } \\
\text { платфрорму Alfa Digital }\end{array}$ \\
\hline Taryan Group & Будівництво & $\begin{array}{l}\text { Зараз Taryan Group будує вежі Taryan Towers з } \\
\text { двоповерховими скляними мостами, рестораном, } \\
\text { парком, зоною інновацій та розваг на дахах }\end{array}$ \\
\hline Київстар & IT і Телеком & $\begin{array}{l}\text { Компанія оплачує онлайн-навчання співробітників через } \\
\text { Coursera i Lynda. Для менеджерів середньої ланки } \\
\text { введена гейміфікована програма навчання }\end{array}$ \\
\hline Фармак & Фармацевтика & $\begin{array}{l}\text { Заводські лабораторії були трансформовані в } \\
\text { інтелектуальні кластери, де працюють } 35 \text { кандидатів і } \\
\text { докторів наук }\end{array}$ \\
\hline Нова Пошта & $\begin{array}{l}\text { Транспорт } \\
\text { і Логістика }\end{array}$ & $\begin{array}{l}\text { У 2018-2019 роках введено в експлуатацію три } \\
\text { інноваційні термінали у Хмельницькому, Львові та Києві }\end{array}$ \\
\hline
\end{tabular}

Джерело: складено авторами на основі [16]

нянні 3 іноземними компаніями. Досить мало компаній прагнуть оптимізувати власну діяльність та для цього застосовують окремі інноваційні технології. Більшість технологій «Індустрії 4.0» все ще залишаються новими для українських компаній та не знаходять свого втілення у виробничих процесах.

Існують деякі проблеми революції Індустрії 4.0, як технічні, так і соціальні.

Максимізація переваг четвертої промислової революції вимагає масового співробітництва, яке не обмежується корпоративними кордонами, особливо коли справа доходить до того, що всі машини говорять однією мовою. Коли незакінчений продукт прибуває на машину, яка не може прочитати ваш RFID-чіп, тому що він запрограмований на іншій частоті, виробничий процес стає хаосом. Тому визначення загальних платорорм і мов, на яких машини різних компаній вільно спілкуються, залишається одним з основних завдань у поширенні кіберфізичних систем.

Ще одна велика проблема - безпека: створення безпечних мереж - складне завдання, а інтеграція фрізичних систем в Інтернет робить їх більш уразливими для кібератак. 3 ростом промисловості 4.0 виробничі процеси можуть бути тероризовані віддалено, маніпулюючи виробничим протоколом або просто паралізуючи процес. У міру того, як розумні заводи стають все більш поширеними, їх безпека стає все більш нагальною темою.

В результаті четвертої промислової революції фрундаментальними змінами будуть охоплені практично всі сорери життя людини. Виділяються наступні ймовірні наслідки розвитку «Індустрії 4.0»:

- звільнення від рутини, зниження значущості і поступове зникнення фрізичної праці;

- фундаментальна транссрормація економіки, переважний розвиток галузей економіки, що мають доступ до великих масивів даних;

- зростання соціального розшарування за рахунок зникнення значущості величезної кількості професій, інтелектуальні і творчі можливості стануть основною цінністю на ринку праці; 
Інноваційні проекти в аграрному секторі України

\begin{tabular}{|c|c|}
\hline Назва проекту & Характеристика \\
\hline МХП & $\begin{array}{l}\text { У компанії послідовно реалізують інноваційні програми в різних } \\
\text { напрямках бізнесу. У } 2017 \text { році МХП і технологічний кластер Radar Tech } \\
\text { запустили єдиний в країні інкубатор агростартапів - МНР accelerator. } \\
\text { Наймасштабніший інноваційний проект - біогазовий напрямок бізнесу, } \\
\text { сировиною для якого став курячий послід. }\end{array}$ \\
\hline Kernel & $\begin{array}{l}\text { Kernel - лідер з інвестицій в інновації. Ще в } 2016 \text { році в компанії вирішили } \\
\text { об'єднати всі використовувані інноваційні продукти в єдиний проект } \\
\text { \#DigitalAgriBussiness. Система інтегрує внутрішні та зовнішні IT-сервіси } \\
\text { Kernel для глобальної автоматизації процесів виробництва. Серед } \\
\text { виробничих новацій - розширення власних портових потужностей в порту } \\
\text { Чорноморськ і фрормування власного вагонного парку. }\end{array}$ \\
\hline Нібулон & $\begin{array}{l}\text { Компанія створила мережу з } 27 \text { сучасних перевантажувальних терміналів } \\
\text { і комплексів з прийому, зберігання і відвантаження зернових і олійних } \\
\text { культур. За потужністю одночасного зберігання зерна (2,1 млн тонн) це зараз } \\
\text { найбільша термінальна мережа в Україні. У } 2012 \text { році «Нібулон» відкрив } \\
\text { суднобудівно-судноремонтний завод - єдине в Україні підприємство, яке } \\
\text { будує повнокомплектні судна. У } 2019 \text { році компанія ввела в експлуатацію } \\
\text { найдовше спеціалізоване кранове судно класу «річка-море», побудоване } \\
\text { за часів незалежності України, - 140-метровий Nibulon Мах. Зараз фрлот } \\
\text { компанії налічує } 76 \text { суден. Загальна сума інвестицій в реалізацію проектів } \\
\text { компанії в цьому маркетинговому році досягла } 85 \text { млн. дол. }\end{array}$ \\
\hline Астарта & $\begin{array}{l}\text { Компанія розробила портал з управління агробізнесом, який містить } \\
\text { консолідовані дані про земельний банк компанії і допомагає різним } \\
\text { департаментам комунікувати. У компанії також розробляють ІТ-рішення, } \\
\text { які допомагають вирішувати ряд виробничих завдань. Тут активно } \\
\text { впроваджують принципи ощадливого виробництва. }\end{array}$ \\
\hline IMK & $\begin{array}{l}\text { IMК стала ініціатором українських курсів Farm Management. Проект } \\
\text { підтримали } 16 \text { найбільших агрокомпаній країни. }\end{array}$ \\
\hline
\end{tabular}

Джерело: складено авторами на основі [16]

- зникнення рутини і типових завдань у зв'язку з автоматизацією переважної більшості процесів такого роду;

- прозорість світу, обумовлена взаємопроникненням реального і цифррового середовища, новими можливостями цифрового контролю небажаних соціальних явищ і подій.

Висновки. Сучасний світ знаходиться на етапі четвертої промислової революції, іменованої «Індустрія 4.0». Враховуючи високу, основоположну значимість цифрових технологій, програмного забезпечення, взаємодоповнюючої роботи складних систем, неминучою стала поява платформ для забезпечення есрективної роботи даних процесів.

На основі дослідження використання вітчизняними підприємствами технологій «Індустрії 4.0» було визначено, що активно здійсню- ють впровадження інновацій у свою діяльність компаній у таких секторах, як: аграрний, машинобудування, альтернативна енергетика, інформаційні технології та фрармацевтика. Визначено перелік вітчизняних IT-компаній, які здійснюють розробку та виробництво продукції, що відповідає вимогам «Індустрії 4.0» та користується попитом серед світових компаній. Встановлено, що використання технологій «ндустрія 4.0» в Україні найбільш характерне для аграрних компаній. Загалом, визначено, що більшість вітчизняних підприємств не прагнуть до використання технологій «Індустрії 4.0» у власних виробничих процесах та схильні до використання традиційних методів виробництва. Для більш стрімкого впровадження новітніх технологій «Індустрії-4.0» Україні необхідно аналізувати та переймати досвід інших країн.

СПИСОК ВИКОРИСТАНИХ ДЖЕРЕЛ:

1. Schwab, K. The fourth industrial revolution. World Economic Forum. 2016. 172 p. URL: https://law.unimelb. edu.au/_data/assets/pdf_file/0005/3385454/Schwab-The_Fourth_Industrial_Revolution_Klaus_S.pdf

2. Амоша О. Щоб змінилася погода, потрібний не поривчастий вітер, а загальна зміна клімату. Дзеркало тижня. (28 грудня - 13 січня). 2018. № 49-50. 
3. Брюховецька Н., Черних О. Індустрія 4.0 та цифрровізація економіки: можливості використання зарубіжного досвіду на промислових підприємствах України. Економіка промисловості. 2020. № 2(90). С. 116-132.

4. Вишневський В., Вієцька О., Гаркушенко О. та ін. Смартпромисловість в епоху цифрової економіки: перспективи, напрями і механізми розвитку. Київ : Інститут економіки промисловості НАН України, 2018. 192 с.

5. Brynjolfsson, E. \& McAfee, A. The Second Machine Age: Work, Progress, and Prosperity in a Time of Brilliant Technologies. W.W. Norton \& Company. 2017. 384 p.

6. Greengard, S. The internet of things. - (MIT press essential knowledge series). 2015. 73 p. URL: https://pdf.zlibcdn.com/dtoken/5b679f7d51c33516add19be397392938/The_Internet_of_Things_by_Samuel_ Greengard)_5152533_(z-lib.org).pdf

7. Плеханов П. Унікальні і прогресивні технології як передумова четвертої промислової революції. Сучасні тенденції в економіці та управлінні: новий погляд. 2013. № 23. С. 273-275.

8. Rifkin, J. The third industrial revolution [Текст] : how lateral power is transforming energy, the economy, and the world. New York : Palgrave Macmillan, 2011. $291 \mathrm{p}$.

9. Rogers, D. The Digital Transformation Playbook. 2016. 296 p.

10. Ross, A. The Industries of the Future. Simon \& Schuster. 2016. 286 p.

11. Handy Charles, B. Understanding organizations. London, England ; New York, N.Y., USA : Penguin Books, 1993. $445 \mathrm{p}$.

12. Schwab, K. The Fourth Industrial Revolution (First U.S. Edition). New York : Crown Business, 2017. 208 p.

13. Smith, J., Kreuztzer, S., Moeller, C. \& Karlberg, M. Policy Department A: Economic and Scientific Policy Industry 4.0. European Parliament, EU. 2016. 1-94.

14. German standardization roadmap Industrie 4.0 Version 3 / DKE Deutsche Kommission Elektrotechnik Elektronik Informationstechnik in DIN und VDE. URL: https://www.din.de/blob/65354/57218767bd6da1927b181 b9f2a0d5b39/roadmap-i4-0-e-data.pdf

15. Войтко С., Гавриш О., Згуровський О. Якість державного регулювання, ефективність роботи уряду чи план Маршалла на шляху країн до Індустрії-4.0. Економічний вісник НТУУ «КПІ». 2018. № 15. DOI: https://doi.org/10.20535/2307-5651.15.2018.131530

16. ТОП-50 інноваційних компаній України. URL: https://delo.ua/business/top-50-innovacionnyh-kompanijukrainy-361631/

17. Офріційний сайт PLC Ukrlandfarming. URL: https://www.ulf.com.ua/en/

18. Врятувати майбутнє: перший рейтинг інноваційних компаній України. URL: http://forbes.net.ua/ua/ magazine/forbes/1416757-vryatuvati-majbutne-pershij-rejting- innovacijnih-kompanij-ukrayini\#17

19. Аналітичний звіт «Індустрія 4.0 в машинобудуванні. Стан в Україні та перспективи розвитку». Ассоціація підприємств промислової автоматизації України. URL: https://industry4-0-ukraine.com.ua/2018/10/18/ аналітичний-звіт-індустрія-4-0-в-машино/

\section{REFERENCES:}

1. Schwab, K. (2016) The fourth industrial revolution. World Economic Forum, 172 p. Retrieved from: https://law.unimelb.edu.au/_data/assets/pdf_file/0005/3385454/Schwab-The_Fourth_Industrial_Revolution_ Klaus_S.pdf

2. Amosha, O.I. (2018) To change the weather, you do not need gusty winds, but general climate change. Mirror of the week. (December 28 - January 13), no. 49-50. (in Ukrainian)

3. Bryukhovetskaya, N. \& Chernykh, O. (2020) Industry 4.0 and digitalization of the economy: opportunities for using foreign experience at industrial enterprises of Ukraine. Industrial Economics, 2(90), 116-132. (in Ukrainian)

4. Vishnevsky, V., Vietskaya, O. \& Garkushenko, O. et al. (2018) Smart industry in the digital economy: prospects, directions and mechanisms of development. Kyiv: Institute of industrial economics of the National Academy of Sciences of Ukraine, 192 p. (in Ukrainian)

5. Brynjolfsson, E. \& McAfee, A. (2017) The Second Machine Age: Work, Progress, and Prosperity in a Time of Brilliant Technologies. W.W. Norton \& Company, 384 p.

6. Greengard, S. (2015) The internet of things. (MIT press essential knowledge series), 73 p. Retrieved from: https://pdf.zlibcdn.com/dtoken/5b679f7d51c33516add19be397392938/The_Internet_of_Things_ by_Samuel_Greengard)_5152533_(z-lib.org).pdf

7. Plekhanov, P. (2013) Unique and advanced technologies as a prerequisite for the Fourth Industrial Revolution. Current trends in economics and management: a new perspective, 23, 273-275. (in Ukrainian)

8. Rifkin, J. (2011) The third industrial revolution [text]: how lateral power is transforming energy, the economy, and the world. New York: Palgrave Macmillan, $291 \mathrm{p}$. 
9. Rogers, D. (2016) The Digital Transformation Playbook, 296 p.

10. Ross, A. (2016) The Industries of the Future. Simon \& Schuster, 286 p.

11. Handy Charles, B. (1993) Understanding organizations. London, England; New York, N.Y., USA: Penguin Books, $445 \mathrm{p}$.

12. Schwab, K. (2017) The Fourth Industrial Revolution (First U.S. Edition). New York: Crown Business, 208 p.

13. Smith, J., Kreuztzer, S., Moeller, C. \& Karlberg, M. (2016) Policy Department A: Economic and Scientific Policy - Industry 4.0. European Parliament, EU, 1-94.

14. German standardization roadmap Industrie 4.0 Version 3 / DKE Deutsche Kommission Elektrotechnik Elektronik Informationstechnik in DIN und VDE. Retrieved from: https://www.din.de/blob/65354/57218767bd6da1927b181 b9f2a0d5b39/roadmap-i4-0-e-data.pdf

15. Voitko, S., Gavrish, O. \& Zgurovsky O. (2018) Quality of government regulation, efficiency of government work, or the Marshall Plan for countries ' path to Industry-4.0. Economic Bulletin of NTUU «KPI», no. 15. DOI: https://doi.org/10.20535/2307-5651.15.2018.131530 (in Ukrainian)

16. TOP-50 Innovative Companies in Ukraine. Retrieved from: https://delo.ua/business/top-50-innovacionnyh-kompanij-ukrainy-361631/ (in Ukrainian)

17. Official website of PLC Ukrlandfarming. Retrieved from: https://www.ulf.com.ua/en/ (in Ukrainian)

18. Save the future: the first rating of innovative companies in Ukraine. Retrieved from: http://forbes.net.ua/ua/ magazine/forbes/1416757-vryatuvati-majbutne-pershij-rejting- innovacijnih-kompanij-ukrayini\#17 (in Ukrainian)

19. Analytical report «Industry 4.0 in Mechanical Engineering. State in Ukraine and development prospects». Association of industrial automation enterprises of Ukraine. Retrieved from: https://industry4-0-ukraine.com.ua/ 2018/10/18/аналітичний-звіт-індустрія-4-0-в-машино/ (in Ukrainian) 